\title{
Optimization of palm oil biodiesel production using response
} surface methodology

Otimização na produção de biodiesel de óleo de palma utilizando a metodologia de superfície de resposta

Flávio Castro da Silva ${ }^{1}$ (D) Juan Fernando Herrera Guardiola ${ }^{1}$ (D), Luciana Pinto Teixeira ${ }^{2}$ (D), Ana Caroline Lopes Maria ${ }^{1}$ (D), Luan Alves de Souza ${ }^{1}$ (D), André Luiz Belém ${ }^{1}$ (1)

\begin{abstract}
A B S T R A C T
The purpose of this paper was to analyze palm oil biodiesel production under different conditions and to verify the relationships between production variables in order to optimize biofuel production using response surface methodology (RSM). Biodiesel was produced through transesterification process by methyl route and alkali catalyst $(\mathrm{NaOH}) 1 \%(\mathrm{~m} / \mathrm{m})$. The analyzed variables were: four molar ratios $(3: 1,4: 1,6: 1$ and $8: 1)$; three temperature reactions $\left(45^{\circ}, 52^{\circ}\right.$ and $\left.60^{\circ} \mathrm{C}\right)$; and three time reactions $(40,60$ and 80 minutes). For the palm oil biodiesel production, the highest yield was $93 \%$, obtained via a molar rate of $3: 1,52^{\circ} \mathrm{C}$ and 60 minutes. This result differs from previous studies that found a higher yield with molar ratio increases, implying greater expenses of methanol. Kinetic viscosity and specific mass were also analyzed, and the values are within the Brazilian, American, and European standards. The results showed that the most influent factor in biodiesel production was the molar rate. In relation to the biodiesel characterization, using the RMN $\mathrm{H} 1$ technique, it was possible to obtain the transesterification reaction yield of $79.50 \%$ for the $3: 1$ palm oil biodiesel. Through gas chromatography, it can be verified that the predominant fatty acids in the samples were palmitic and oleic acids. .
\end{abstract}

Keywords: methyl esters; biofuel viscosity; biofuel specific mass; production efficiency.

\section{RE S U M 0}

O objetivo deste trabalho foi analisar a produção de biodiesel de óleo de palma em diferentes condições e verificar as relações entre variáveis de produção para otimizar a produção de biocombustíveis usando a metodologia da superfície de resposta (response surface methodology - RSM). O biodiesel foi produzido através do processo de transesterificação via rota metílica e com catalisador alcalino $(\mathrm{NaOH})$ a $1 \%(\mathrm{~m} / \mathrm{m})$. As variáveis analisadas foram: quatro razões molares (3:1, 4:1, 6:1 e 8:1); três temperaturas de reação $\left(45^{\circ}, 52^{\circ}\right.$ e $\left.60^{\circ} \mathrm{C}\right)$ e três tempos de reação (40, 60 e 80 minutos). Para a produção de biodiesel de óleo de palma, o maior rendimento foi de $93 \%$, obtido na razão molar de $3: 1,52^{\circ} \mathrm{C}$ e 60 minutos. Esse resultado difere de outros estudos que encontraram maior rendimento com o aumento da razão molar, implicando em maiores gastos com metanol. A viscosidade cinética e a massa específica também foram analisadas, e os valores estão dentro dos padrões brasileiro, americano e europeu. Os resultados mostraram que o fator mais influente na produção de biodiesel foi a razão molar. Em relação à caracterização do biodiesel, pela técnica de RMN $1 \mathrm{H}$, foi possível obter o rendimento da reação de transesterificação de 79,50\% para o biodiesel 3:1 de óleo de palma. Por meio da cromatografia gasosa, pode-se verificar que os ácidos graxos predominantes nas amostras foram os ácidos palmíticos e oleico.

Palavras-chave: ésteres metílicos; viscosidade de biocombustível; massa específica de biocombustível; eficiência de produção.

\footnotetext{
${ }^{1}$ Universidade Federal Fluminense - Niterói (RJ), Brazil.
}

2Universidade Santa Úrsula - Rio de Janeiro (RJ), Brazil.

Correspondence address: Flávio Castro da Silva - Rua Passo da Pátria, 156, Bloco E, sala 301 - São Domingos - CEP: 24210-240 - Niterói (RJ)

Brazil. E-mail: flaviocastro@id.uff.br.

Conflicts of interest: the authors declare that there are no conflicts of interest.

Funding: Coordenação de Aperfeiçoamento de Pessoal Nível Superior - Brasil (CAPES) - Funding code 001, and Pós-Graduação em Engenharia de Biossistemas (PGEB).

Received on: 06/03/2020. Accepted on: 10/30/2020.

https://doi.org/10.5327/Z21769478825 


\section{Introduction}

Alternative fuel sources have been widely studied due to the non-renewable character of the current and most used energy source, oil. For Razack and Duraiarasan (2016), biodiesel has emerged as the main substitute for petroleum diesel. Biodiesel promotes sustainable development through energy savings, in addition to presenting characteristics, such as low toxicity and low emission of polluting gases (Ambat et al., 2018).

Biodiesel is a renewable energy source, biodegradable and derivates from renewable sources, such as vegetable oils and animal fat. There are several technologies for biodiesel production, such as cracking, esterification and transesterification, which involve the management of variables, such as the molar ratio of alcohol:oil, temperature, time, and catalyst amount, determinants for the efficiency of biodiesel production. The transesterification process of fatty acids present in oils and fats is the most common and can be carried out using ethanol (ethyl route) or methanol (methyl route), which generally present better yields in the presence of an acid or basic catalyst (Rodrigues et al., 2011; Victorino et al., 2016; Abdullah et al., 2017; Gonçalves et al., 2019).

In both processes the production of glycerol is obtained as a by-product, which contributes in the increasing biodiesel competitiveness, since this substance can be used as raw material in the production of paints, pharmaceuticals, and textiles.

Biodiesel or fatty acid methyl ester (FAME), when using methanol, or fatty acid ethyl ester (FAEE), when using ethanol, is a fuel that can be applied pure or mixed with petroleum derived diesel in various proportions in internal combustion engines without the need for mechanical modifications in the engine (Rincón et al., 2014).

Brazilian national law no. 12,490 of September 16, 2011 (in item XXIV of Article 6) defines biofuel as a "substance derived from renewable biomass, such as biodiesel, ethanol and other substances established in Brazilian National Agency of Petroleum, Natural Gas and Biofuels (ANP) regulations, which can be used directly or through changes in internal combustion engines or for other types of power generation, being able to replace fossil fuels partially or totally" (Brasil, 2011).

Due to its origin, biodiesel provides lower environmental impacts when compared to diesel fuel, emitting less particulate material, carbon dioxide $\left(\mathrm{CO}_{2}\right)$ and nitrogen oxides $\left(\mathrm{NO}_{\mathrm{X}}\right)$, which are gases that contribute to the greenhouse effect. When this biofuel shows similar characteristics to diesel fuel, it is able to replace it as an energy source (Kumar et al., 2016).

However, as stated by Ge et al. (2020), a possible disadvantage is that viscosity and density tend to be slightly higher in biodiesel than in diesel due to the presence of saturated and unsaturated long chain fatty acids.

The USA is the country with the highest biofuel production, followed by Brazil (Sawin et al., 2017). According to Sawin et al. (2017), the total production of biofuels in Brazil was 30.8 billion liters in 2016, 27 billion of which were ethanol and 3.8 billion were biodiesel. In Brazil, biodiesel has soy oil and pork fat as its main feedstocks, with a participation of 72.51 and $14.93 \%$, respectively, while palm oil represents only $0.16 \%$. These facts show the minor participation on a wide variety of potential raw materials for biodiesel production, so it is necessary to increase the participation of raw materials in matrix, especially of products with highly productive yield such as the palm oil crop.

According to Feroldi et al. (2014), palm is considered the raw material with the highest oil productivity among the oilseeds for consumption around the world, with 20 to $22 \%$ of oil and a yield of four to six tons per hectare each year. Besides, palm oil is also a significant profitable oil for biodiesel production due to its compositional characteristics, high productivity with low cost, whole year well distributed production and no competition with other crops for feeding purposes. Nowadays in Brazil, most palm oil plantations are concentrated in the states of Pará, Amazonas, Amapá, and Bahia (D’Agosto et al., 2015). Moreover, palm oil biodiesel production is encouraging a new segment for the productive chain that is strengthening, generating, and multiplying employment and increasing income in the agricultural phase, input market and services and transport, storage, blending and biodiesel marketing activities (Lebid and Henkes, 2015).

The cultivation of the African palm (Elaeis guineenses), originating from the Gulf of Guinea on the West coast of Africa, is an oleaginous plant species from which oil is extracted out of its fruit mesocarp. This palm has a life cycle of 20 to 30 years and begins to produce clusters at the age of 3.5 years after planting, reaching its peak between 7 and 15 years, after which it begins to decrease slowly until the 25 th year. The favourable development conditions are moderate air temperature, solar radiation associated with a good distribution of precipitation with 2,000 $\mathrm{mm}_{\text {year }}{ }^{-1}$ and deep soils without compaction, with a maximum slope of 5\% and an altitude up to 600 meters (Kuss et al., 2015).

Palm oil is the main raw stock for biodiesel production in Malaysia (Mekhilef et al., 2011), which is one of the leading palm oil producers in the world. There are many advantages and disadvantages from the economic, social, and environmental features of the Malaysian biodiesel palm production.

Apart from the economic aspect, the environmental issue is a major fact. According to Kong et al. (2014), the producing biochar from palm oil biomass provides promising co-benefits, including the generation of renewable electricity, liquid and gas biofuels, large amounts of heat or low-pressure steam and the potential of a net withdrawal of carbon dioxide from the atmosphere. In the future, biochar alone is not going to be enough to reduce Greenhouse Gas Protocol (GHG) to manageable safety levels. However, it can be implemented and integrated to the palm oil producing countries using many different approaches to create a substantial positive impact on the challenges of climate change and crop productivity.

Different studies carried out by Ali and Tay (2013), Sukjit and Punsuvon (2013), Feroldi et al. (2014), Wong et al. (2015), Anguebes-Franseschi et al. (2016), among others, analysed the variables associated with the biodiesel production from palm oil, and found that the molar ratio ethanol:oil, temperature and stirring time are the most important factors involved in the reaction. Some authors, such as Ali and 
Tay (2013) and Feroldi et al. (2014), found the optimal conditions for palm oil biodiesel production using methanol in the transesterification process: the methanol:oil molar ratio of $6: 1$, reaction time of $60 \mathrm{~min}$ utes and temperature of $60^{\circ} \mathrm{C}$ with $1 \%$ of $\mathrm{KOH}$ as a catalyst, resulting in $88 \%$ yield. Likewise, Anguebes-Franseschi et al. (2016) obtained a yield of $90 \%$ in palm oil biodiesel production with a reaction temperature of $56^{\circ} \mathrm{C}, 135$ minutes, and a $\mathrm{NaOH}$ catalyst proportion of $0.65 \%$.

It is important to monitor the process from the formation of the main product, the fatty esters, in the transesterification. Thus, high-performance liquid chromatography, gas chromatography, proton nuclear magnetic resonance ( $1 \mathrm{H} \mathrm{NMR}$ ) and thin layer chromatography methods are used. Among these techniques, gas chromatography is considered the most effective to determine the amount of fatty acid esters present in the biodiesel composition (Marques et al., 2010).

Using response surface methodology (RSM), Sukjit and Punsuvon (2013) determined that the best conditions were a molar ratio of $7: 1$ methanol:palm oil, temperature of $60^{\circ} \mathrm{C}$ with 70 minutes of reaction time and a proportion of $1.2 \%$ of $\mathrm{KOH}$ catalyst, resulting in a $96.24 \%$ yield. Using RSM, the highest yield obtained in the reaction with palm oil was $97.67 \%$ with a molar ratio of $13.04: 1$ methanol:oil, time of 2.67 hours and a catalyst proportion of $3.60 \%$ (Wong et al., 2015).

Thus, taking into account the different studies about molar ratio, temperature and reaction time for biodiesel production, as well as the importance of determining a more efficient process for the production of renewable energies, this paper aimed to establish the process with the highest yield using RSM in the production of palm oil biodiesel, testing the values of factors, such as molar ratio, temperature and time, as well as analyzing the kinetic viscosity and specific mass.

\section{Materials and Methods}

\section{Biodiesel production}

The structure of this paper comprised two steps: the first involved the biodiesel produced experimentally and the second consisted in biodiesel characterization and elaboration of the response surface. The palm oil biodiesel production and characterization were performed at the Universidade Federal Fluminense (UFF, Brazil). For biodiesel production, palm oil and methanol were used and $\mathrm{NaOH}$ was the catalyst.

The different characteristics of molar ratio, temperature and time were considered for the experimental analyses of biodiesel production. The data were obtained for three temperatures $\left(45,52\right.$ and $\left.60^{\circ} \mathrm{C}\right)$, three production times (40,60 and 80 minutes), and four molar ratios of methanol:oil (3:1, 4:1, 6:1, 8:1), as shown in Table 1.

Table 1 - Analysis of variation sources.

\begin{tabular}{|c|c|}
\hline Molar ratio (methanol:oil) & $3: 1,4: 1,6: 1,8: 1$ \\
\hline Temperature $\left({ }^{\circ} \mathrm{C}\right)$ & $45,52,60$ \\
\hline Time $(\mathrm{min})$ & $40,60,80$ \\
\hline
\end{tabular}

Palm oil is red due to the presence of carotenoids and is rich in vitamins, coenzymes, and sterols (Porcayo-Calderon et al., 2017). In addition, it is more saturated than soybean oil and rapeseed due to its higher amount of fatty acids, such as palmitic (C16:0), stearic (C18:0), oleic (C18:1) and linoleic (C18:2) acids (Issariyakul and Dalai, 2014). High-quality palm oil is mainly used in the food industry, and low-quality (non-edible) oil is used to produce soap, waxes, cosmetics, biofuels, and other types of goods (Porcayo-Calderon et al., 2017).

Table 2 shows the fatty acid composition of palm oil. It is possible to observe $50 \%$ of saturated fatty acids (SFA), mainly palmitic acid (44\%), and lower amounts of stearic acid (5\%), 40\% of monounsaturated fatty acids (AGMI), mainly oleic acid and $10 \%$ of polyunsaturated fatty acids (PUFA), mainly linoleic acid.

Biodiesel was obtained via alkali transesterification reaction. Initially, the quantities of palm oil, methanol and $\mathrm{NaOH}$ based on the treatment were weighed. Consequently, the oil was heated in the corresponding treatment temperature $\left(45,52\right.$ and $\left.60^{\circ} \mathrm{C}\right)$ and then mixed with the methanol and $\mathrm{NaOH}$ mixture in the magnetic stirrer at the temperature and reaction time of the treatment. After the reaction time, the biodiesel was separated from the glycerol phase and washed with distilled water and hydrochloric acid, heated at $105^{\circ} \mathrm{C}$ and finally filtered. The mass yield production of each treatment was determined from the biodiesel mass divided by oil mass, as shown in Equation 1.

$$
\text { Yield }(\%)=(\text { biodiesel mass }(\mathrm{g})) /(\text { oil mass }(\mathrm{g}))
$$

\section{Biodiesel characterization}

The biodiesel characterization was carried out according to the Brazilian (ABNT), American (ASTM) and European (EN ISO) standards (Table 3). A specific mass at $20^{\circ} \mathrm{C}$ was determined, as well as biodiesel kinetic viscosity, separated according to molar ratio (3:1, 4:1, 6:1 and 8:1). The Brazilian National Agency of Petroleum, Natural Gas and Biofuels (ANP) defines biodiesel as a fuel composed of alkyl esters of long-chain carboxylic acids, produced through the transesterifica-

Table 2 - Fatty acid composition of palm oil.

\begin{tabular}{|l|c|c|}
\hline Fatty Acid Name & & Composition (\%) \\
\hline Lauric & $(12: 0)$ & 0.2 \\
\hline Myristic & $(14: 0)$ & 1.1 \\
\hline Palmitic & $(16: 0)$ & 44 \\
\hline Stearic & $(18: 0)$ & 4.5 \\
\hline Oleic & $(18: 1)$ & 39.2 \\
\hline Linoleic & $(18: 2)$ & 10.1 \\
\hline Linolenic & $(18: 3)$ & 0.4 \\
\hline Arachidic & $(20: 0)$ & 0.1 \\
\hline
\end{tabular}

Source: adapted from Mancini et al. (2015). 
tion and/or esterification of fatty substances, of fats from vegetable or animal origins (Brasil, 2014).

The specific mass was determined using a pycnometer with biodiesel at $20^{\circ} \mathrm{C}$ (Lima et al., 2010). The known volume using a pycnometer was $50 \mathrm{~mL}$, and the specific mass was calculated applying Equation 2, considering the mass difference between empty and full pycnometers.

$$
\rho=(\text { fpm-epm }) / \mathrm{pv}^{\star} 1000
$$

In which:

$\rho=$ specific mass of biodiesel $\left(\mathrm{kg} \mathrm{m}^{-3}\right)$;

$\mathrm{fpm}=$ full pycnometer mass $(\mathrm{g})$;

epm = empty pycnometer mass $(\mathrm{g})$;

$\mathrm{pv}=$ pycnometer volume $(\mathrm{mL})$.

Kinetic viscosity was calculated from the dynamic viscosity divided by specific mass. Dynamic viscosity was determined using rheometer Haake RS50, and specific mass was calculated. Biodiesel samples at $40^{\circ} \mathrm{C}$ (ASTM, 2012) were used for these analyses.

\section{Biodiesel characterization by hydrogen} nuclear magnetic resonance

$1 \mathrm{H}$ NMR spectrometry characterization of palm oil and biodiesel samples with higher mass yield was carried out at the Multi-Nuclear Magnetic Resonance Laboratory (LaReMN) at UFF (Brazil). The samples were diluted in deuterated chloroform $(\mathrm{CDCl} 3)$ and analyzed on a Varian spectrometer - VNMRS 300MHz. Tetramethylsilane (TMS) was used as reference, according to the methodology proposed by $\mathrm{Fa}$ gundes (2011)

\section{Gas chromatography}

Samples with the highest mass yield biodiesel were analyzed qualitatively in the gas chromatograph coupled to mass spectrometry (GC-MS) GCMS-QP2010 (Shimadzu, Tokyo, JP) using the following conditions: injection with flow division in the ratio of 1:20; DB5-MS column $(30 \mathrm{~m} \times 0.25 \mathrm{~mm}$ D.I. and $1 \mu \mathrm{m}$ of $5 \%$ phenyl-polydimethylsiloxane); the carrier gas used was $\mathrm{He}(99.999 \%$ pure) under a constant flow of $3 \mathrm{~mL} \mathrm{~min}^{-1}$; oven temperature setting was $50-180^{\circ} \mathrm{C}$ with heating rate of $8^{\circ} \mathrm{C} \mathrm{min}^{-1}, 180-230^{\circ} \mathrm{C}$ with heating rate of $5^{\circ} \mathrm{C} \mathrm{min}^{-1}, 230-310^{\circ} \mathrm{C}$ with heating rate of $20^{\circ} \mathrm{C}$ $\mathrm{min}^{-1}$, followed by isotherm for 15 minutes. The chromatographic profiles were made in comparison with the Nist 147 library (US National Institute of Standards and Technology 147), indicating the presence of some methyl esters in the samples. The distribution of the observed substances was determined by standardizing the area of each present peak, that is, in percentage of relative chromatographic area.

\section{Degree of transesterification conversion}

The biodiesel sample with the highest mass yield had its transesterification reaction characterized by the spectrum of nuclear magnetic resonance. The conversion of oil into biodiesel was calculated according to Equation 3, following the methodology proposed by Ruschel et al. (2016). Based on this equation, the conversion is determined by the integration of the biodiesel sample 1H NMR signals. The integration of each spectrum was generated using the MestreNova software v. 12.0.

$$
\mathrm{C}_{\mathrm{T}}=\left(\left(\mathrm{I}_{\mathrm{CH} 3} / 3\right) /\left(\mathrm{I}_{\mathrm{CH} 2} / 2\right)\right)^{\star} 100
$$

In which:

$\mathrm{C}_{\mathrm{T}}=$ the conversion rate of the transesterification process;

$\mathrm{I}_{\mathrm{CH} 2}$ and $\mathrm{I}_{\mathrm{CH} 3}=$ obtained integrating the signals attributed to hydrogen of methylene group adjacent to carbonyl and hydrogen of methyl ester group, respectively.

As mentioned, the signal from methylene group adjacent to carbonyl (2.1-2.4 ppm) is used in the conversion parameter, as it is present in all triglyceride derivatives.

\section{Response surface}

In order to elaborate the response surface, the Matlab Software ${ }^{\circledast}$ (academic version) was used. The response surface was obtained for the variables molar ratio $(\mathrm{x})$, reaction time $(\mathrm{y})$, temperature $(\mathrm{z})$, and yield (response), shown in Equation 4, using the linear interpolation method. Maximum yield was then obtained from the maximum value of the surface in Equation 4.

$$
\text { Yield }=\mathrm{F}(\mathrm{xq}, \mathrm{yq}, \mathrm{zq})
$$

\begin{tabular}{|c|c|c|c|c|}
\hline \multirow{2}{*}{ Characteristic } & \multirow{2}{*}{ Limit } & \multicolumn{3}{|c|}{ Method } \\
\hline & & ABNT & ASTM D & EN ISO \\
\hline Specific mass at $20^{\circ} \mathrm{C}$ & 850 to $900 \mathrm{~kg} \cdot \mathrm{m}^{-3}$ & $\begin{array}{c}7148 \\
14065\end{array}$ & $\begin{array}{l}1298 \\
4052\end{array}$ & $\begin{array}{l}\text { EN ISO } 3675 \\
\text { EN ISO } 12185\end{array}$ \\
\hline Kinematic viscosity at $40^{\circ} \mathrm{C}$ & 3 to $6 \mathrm{~mm}^{2} \cdot \mathrm{s}^{-1}$ & 10441 & 445 & EN ISO 3104 \\
\hline
\end{tabular}

Table 3 - Biodiesel specifications established by Brazilian, American, and European regulations.

Source: adapted from Brasil (2014). 


\section{Results and Discussion}

\section{Specific mass}

The specific mass results of biodiesel samples at $20^{\circ} \mathrm{C}$ are presented in Table 4. The results obtained are according to the Brazilian (ABNT), American (ASTM) and European (EN ISO) standards (Table 3), which demand a specific mass value from 850 to $900 \mathrm{~kg} \mathrm{~m}^{-3}$. It is also possible to observe that the molar ratio did not significantly alter the specific mass values of the produced biodiesel.

According to Lôbo et al. (2009), biodiesel specific mass is directly linked to its molecular structure. The higher the length of the alkyl ester carbon chain, the greater the density. However, density can decrease with a greater number of unsaturation present in the molecule. Density can also be affected by the presence of impurities, such as alcohol or adulterants. Compared to diesel, biodiesel is less compressible and denser, causing a decrease in the calorific value and increasing consumption.

The specific mass is a determinant parameter of maximum biodiesel percentage in the mixture with diesel, since mixtures with a high proportion of biodiesel or those which diesel density is close to the upper limit allowed could exceed the limits established by the standards (Avellaneda, 2010).

Based on Ali et al. (2014), the raw material used in the production process has a direct influence on the specific biodiesel mass. The results presented for specific mass are according to the ones obtained by Ali et al. (2012), Vargas (2010), Sarkar and Bhattacharyya (2012). These authors indicated values for specific mass from palm oil biodiesel as $867,871.6$ and $874 \mathrm{~kg} \mathrm{~m}^{-3}$, according to Ali et al. (2012), Vargas (2010), Sarkar and Bhattacharyya (2012)".

Table 4 - Specific mass of biodiesel at $20^{\circ} \mathrm{C}$ according to molar ratio*.

\begin{tabular}{|c|c|}
\hline Molar ratio & Specific mass $\left(\mathrm{kg} \mathrm{m}^{-3}\right)$ \\
\hline $3: 1$ & $871.90 \mathrm{a}$ \\
\hline $4: 1$ & $872.46 \mathrm{a}$ \\
\hline $6: 1$ & $872.26 \mathrm{a}$ \\
\hline $8: 1$ & $871.58 \mathrm{a}$ \\
\hline
\end{tabular}

*Average values followed by the same letter do not differ in the $5 \%$ probability level by Tukey test.

Table 5 - Biodiesel kinetic viscosity according to molar ratio ${ }^{\star}$.

\begin{tabular}{|c|c|}
\hline Molar ratio & Kinetic viscosity $\left(\mathrm{mm}^{2} \mathrm{~s}^{-1}\right)$ \\
\hline $3: 1$ & $4.89 \mathrm{a}$ \\
\hline $4: 1$ & $5.45 \mathrm{~d}$ \\
\hline $6: 1$ & $5.39 \mathrm{c}$ \\
\hline $8: 1$ & $5.09 \mathrm{~b}$ \\
\hline
\end{tabular}

${ }^{*}$ Average values followed by different letter differ in the $5 \%$ probability level by Tukey test.

\section{Kinetic viscosity}

The kinetic viscosity results obtained are presented in Table 5 and are according to the Brazilian (ABNT), American (ASTM) and European (EN ISO) standards (Table 3 ), which require values of 3 to $6 \mathrm{~mm}^{2} \mathrm{~s}^{-1}$.

Several authors, such as Ali et al. (2012), Yusop et al. (2018), Kim et al. (2019), Tziourtzioumis and Stamatelos (2019), Yoon et al. (2019), and Ong et al. (2020), who produced biodiesel from palm oil, obtained kinematic viscosity values between 4.56 and $4.74 \mathrm{~mm}^{2} . \mathrm{s}^{-1}$.

According to Zahan and Kano (2018), biodiesel produced from palm oil has better properties compared to biodiesel produced from other raw materials, including kinematic viscosity. As explained by Yusop et al. (2018), fuel viscosity plays an important role in engine injection systems, as lower viscosities cause injectors and pumps to leak, interfering with the engine's power production. In addition, viscosity also interferes with atomization and spraying within the combustion chamber.

\section{Hydrogen nuclear magnetic resonance}

Using the hydrogen nuclear magnetic resonance (1H NMR) technique, it is possible to determine whether the transesterification reaction of triglycerides in monoesters occurred directly. The results from RMN1 H were similar for both palm oil and 3:1 molar ratio biodiesel. Figure 1 shows the $1 \mathrm{H}$ NMR spectrum of palm oil, in which the presence of a multiplet signal in the area of 4-4.4 ppm can be observed. This area shows the presence of hydrogen characteristic of triglycerides.

After the transesterification reaction, the $1 \mathrm{H}$ NMR spectrum in the produced biodiesel (Figure 1B) has no sign of the characteristic area of triglycerides $4-4.4 \mathrm{ppm}$. In addition, it is also possible to observe that in this spectrum, unlike the oil sample, a singlet is observed in the 3.4-3.7 ppm area, and this signal is attributed to the hydrogen of the methoxy group - $\mathrm{OCH} 3$ present in the produced methyl esters.

Furthermore, it appears that the signal from the 2.1-2.4 ppm area was highlighted, as it can be observed both in the source material (vegetable oil) and in the biodiesel samples. This area is attributed to the hydrogen in the carbonyl $(\alpha-\mathrm{CH} 2)$ adjacent group. In addition to the chemical information that this signal provides, it is also used to determine the degree of the transesterification conversion process.

The main chemical shifts (ppm) observed in the spectra of the produced biodiesel are shown in Table 6 .

Analyzing the $1 \mathrm{H}$ NMR spectrum of 3:1 palm biodiesel, a triplet with an integration of approximately $3 \mathrm{H}$ is observed in the displacement range of $0.92-0.84 \mathrm{ppm}$ in relation to TMS. In the displacement range of 1.27-1.21 ppm, a singlet with an integration of approximately $13 \mathrm{H}$ is observed. A singlet is observed in the displacement range of 1.56-1.59 ppm with an integration of approximately $2 \mathrm{H}$. In the displacement range of 2.32-2.28 ppm, a triplet with an integration of approximately $2 \mathrm{H}$ is observed. In the displacement range of 3.69-3.65 ppm, a singlet with an integration of approximately $3 \mathrm{H}$ is observed 
and in the displacement range of 5.42-5.29 ppm a multiplet with an integration of approximately $1 \mathrm{H}$ is observed.

Analysis of the data from the $1 \mathrm{H}$ NMR spectrum of the produced biodiesel proved that the transesterification reaction occurred observing the disappearance of the signals from the area of 4-4.4 ppm, indicating the disappearance of the hydrogen attributed to the triglycerides and the appearance of the singlet in the 3.5-3.7 ppm area, which is attributed to the hydrogen of the formed ester. The obtained results for chemical displacement and yield were compared to data already described in previous studies.

\section{Transesterification conversion degree}

As shown in Table 7, the $1 \mathrm{H}$ NMR analysis suggested that the yield of the transesterification reaction is mainly associated with the presence or absence of signal in the 4-4.4 ppm area attributed to the triglyceride $\mathrm{H}$. As a result, a $79.50 \%$ conversion rate was observed.

It is important to note that the greater the conversion of biodiesel, the lower the amount of glycerin produced, suggesting that the cotton-coconut mixture has a lower amount of glycerin compared to other oils.

\section{Gas chromatography analysis coupled to mass spectrometry}

In the chromatogram corresponding to the palm oil methyl biodiesel sample (Figure 2), it is evident that the 16-22-minute interval shows signs related to the fatty esters that contribute the most to the composition of palm oil biodiesel. Comparing the experimental data to the data from ANVISA (Brasil, 1999) and Mancini et al. (2015), there is an agreement in relation to the largest compositions, which were oleic and palmitic acids, such as those of a greater area present in the sample (Table 8).

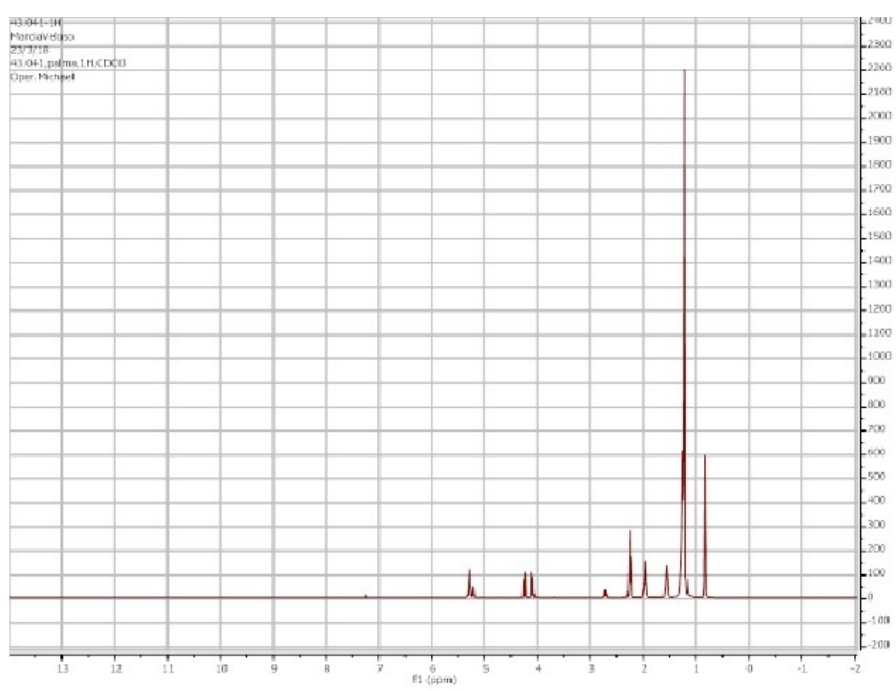

(A)

\section{Statistical analysis}

The software used for statistical analysis was the SISVAR v. 5.6 (Ferreira, 2014) with the Tukey test at a 5\% significance level ( $\mathrm{p}<0.05) .108$ samples were also analyzed in order to estimate the effects in biodiesel production yield of the studied variables and their interactions (Table 9). All three studied variables and the interactions between molar ratio versus temperature and temperature versus time had a significant effect on biodiesel production yield. However, the interaction between molar ratio versus time did not present significant effects.

It can be observed in Figure 3 that the highest yield in biodiesel production (93\%) was obtained in the 3:1 molar ratio with a temperature of $52^{\circ} \mathrm{C}$ and stirring time of 60 minutes. The curves are quadratic regressions over average yield and temperature (or time) for all sets of molar ratios experiments. For the other molar ratios, the yield was lower and decreasing as the molar ratio increased. It can also be observed that the yield variation (between temperatures and stirring times) was lower at the 3:1 molar ratio.

Table 6 - Chemical shift (ppm) of biodiesel samples.

\begin{tabular}{c|c} 
Biodiesel & Chemical shift $(\delta)$ \\
& $1 \mathrm{H} \mathrm{NMR}(\mathrm{CDCl} 3,300 \mathrm{~Hz}): 5.42-5.29$ \\
Palm 3:1 & $(\mathrm{m}, 1 \mathrm{H}) ; 3.69-3.65(\mathrm{~s}, 3 \mathrm{H}) ;$ \\
& $2.32-2.28(\mathrm{t}, 2 \mathrm{H}) ; 1.59-1.56(\mathrm{~s}, 2 \mathrm{H}) ;$ \\
& $1.27-1.21(\mathrm{~s}, 13 \mathrm{H}) ; 0.92-0.84(\mathrm{t}, 3 \mathrm{H})$
\end{tabular}

Table 7 - Conversion rate values for higher mass yield biodiesel.

\begin{tabular}{|c|c|}
\hline Biodiesel & Conversion (\%) \\
\hline Palm 3:1 & 79.50 \\
\hline
\end{tabular}

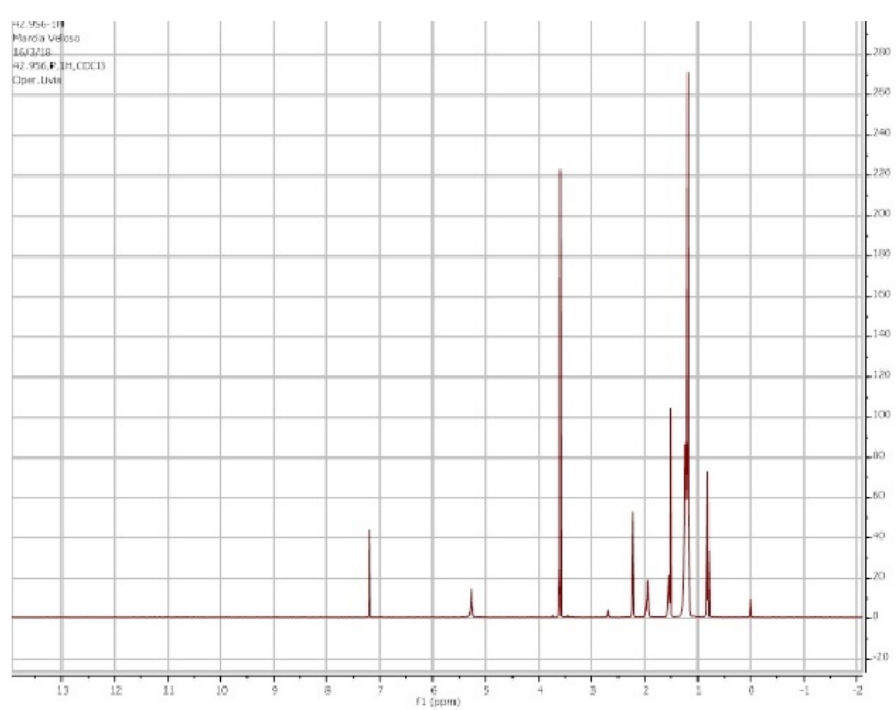

(B)

Figure 1 - 1H NMR spectrum of the source of triglycerides in (A) palm oil and (B) biodiesel formed. 
Figure $3 \mathrm{~A}$ shows the temperature performance in the production of biodiesel from palm. It was expected that the yield would be increased at higher temperatures, since, according to Feng et al. (2017), the molecular interaction between the reagents benefits the increase in the reaction temperature. However, the increase in temperature causes loss of reaction yield. According to Ramos et al. (2011), a possible ex-

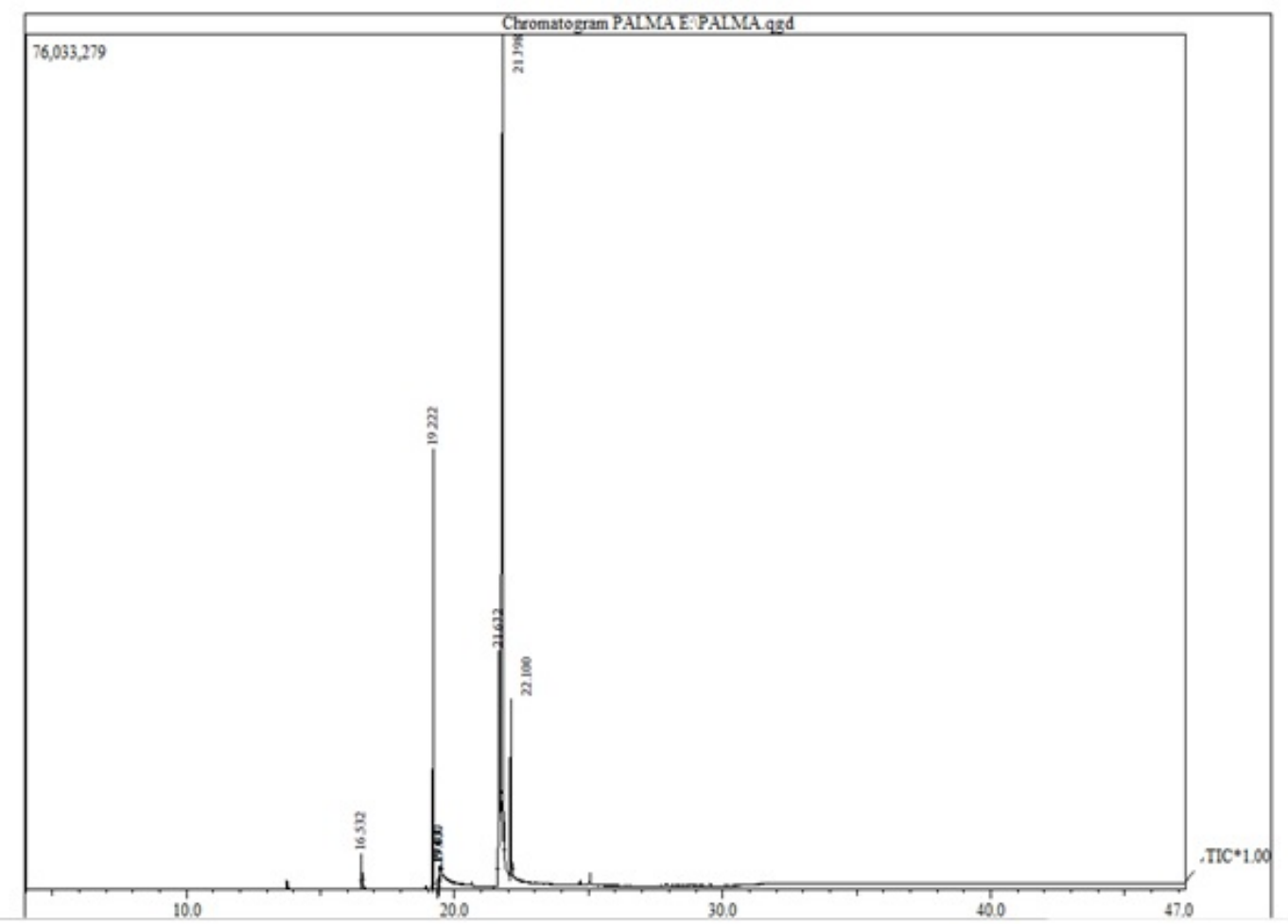

Figure 2 - Palm oil methyl biodiesel chromatogram.

Table 8 - Palm oil biodiesel fatty acid.

\begin{tabular}{|l|c|c|c|c|c|}
\hline Fatty acid & Nomenclature & Retention time (min) & Area (\%) & Mancini et al. (2015) & Brasil (1999) \\
\hline C14:0 & Myristic & 16.53 & 0.82 & 1.1 & $0.5-2$ \\
\hline C16:0 & Palmitic & 19.22 & 16.72 & 44 & $35-47$ \\
\hline C18:0 & Stearic & 21.10 & 8.23 & 4.5 & $3.5-6.5$ \\
\hline C18:1 & Oleic & 21.79 & 64.39 & 39.2 & 10.1 \\
\hline C18:2 & Linoleic & 21.67 & 9.34 & $6.5-15$ \\
\hline
\end{tabular}

Table 9 - Variance analysis of the effect on biodiesel production yield of the studied variables and their interactions.

\begin{tabular}{|c|c|c|c|c|c|}
\hline Source & Degree of freedom & Sum of squares & Mean of square & F-value & $\operatorname{Pr}>\mathrm{Fc}$ \\
\hline Molar ratio & 3 & 0.2213 & 0.0738 & 313.528 & 0.0000 \\
\hline Temperature & 2 & 0.0508 & 0.0254 & 107.849 & 0.0000 \\
\hline Time & 2 & 0.0050 & 0.0025 & 10.592 & 0.0000 \\
\hline Molar ratio*Temperature & 6 & 0.0233 & 0.0039 & 16.530 & 0.0000 \\
\hline Molar ratio ${ }^{\star}$ Time & 6 & 0.0023 & 0.0004 & 1.653 & 0.1429 \\
\hline Temperature ${ }^{\star}$ Time & 4 & 0.0051 & 0.0013 & 5.458 & 0.0000 \\
\hline CV (\%) & 1.78 & & & & \\
\hline Mean & 0.8606 & & & & \\
\hline
\end{tabular}


planation is that the increase in temperature not only favors the desired kinetics, but also the competing reactions such as hydrolysis. Ahiekpor and Kuwornoo also (2010) concluded that low temperatures in the reaction decrease the saponification degree.

Figure $3 \mathrm{~B}$ shows the reaction time effect on the transesterification of palm oil. The yield showed a slight increase when the reaction time went from 40 to 60 minutes in the molar ratio of 3:1. However, the increase in time from 60 to 80 minutes led to a reduction in the reaction yield. For the other molar ratios, the increase in reaction time resulted in decreased yield. These results differ from those of Roschat et al. (2018), which obtained higher yields with increased reaction times.

Figure 4 shows the standardized distribution of production yields, and it is possible to verify that the lower molar ratios (3:1 and 4:1) present a higher density of values in the area of 85 to $90 \%$ yield, with emphasis on the molar ratio of 3:1, which showed greater density in the area of 90 to $95 \%$ of yield. At the highest molar ratios (6:1 and 8:1), the value density was greater in the area of 85 to $90 \%$ yield for the $6: 1$ molar ratio (with a density lower than the $4: 1$ ratio), and in the area of 80 to $85 \%$ yield for the $8: 1$ molar ratio. These values are evidenced by the better performance of the 3:1 molar ratio in the different reaction times studied.

\section{Response surface}

Figure 5 shows the effects of molar ratio, temperature, and time over a response surface of palm oil biodiesel production yield.

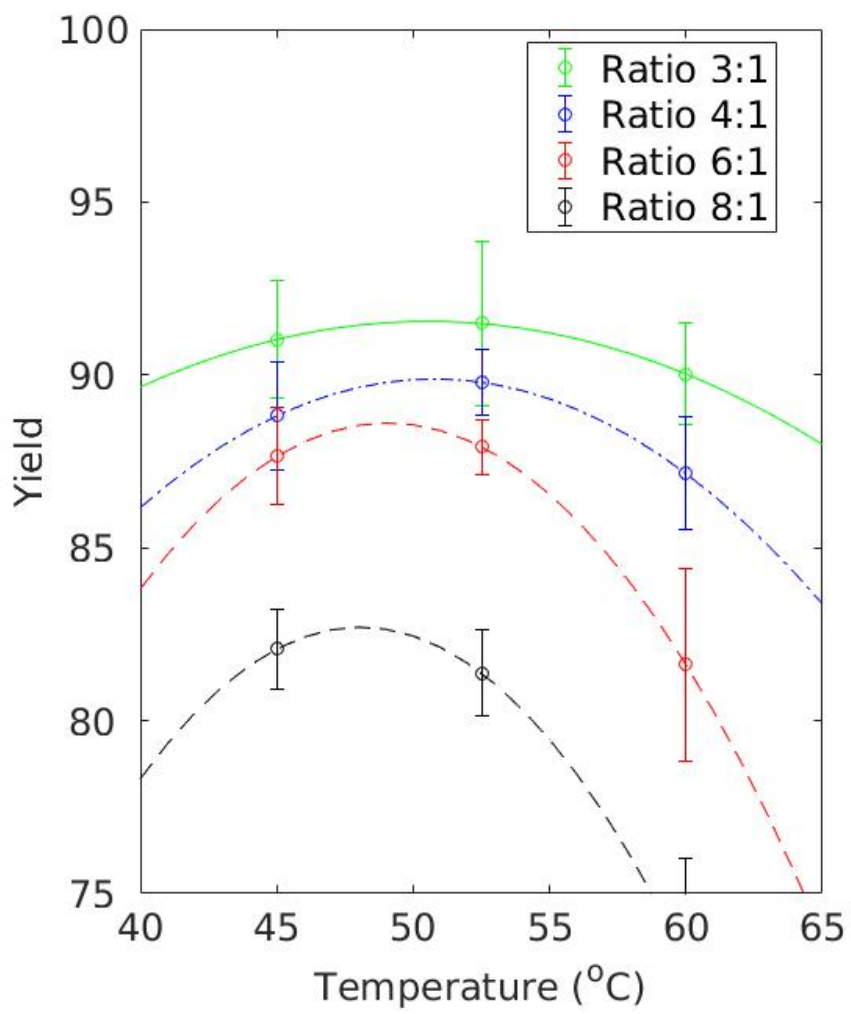

A maximum yield response, indicated by the dark red color, corresponds to a molar ratio of $3: 1$, temperature of $52^{\circ} \mathrm{C}$ and 60 minutes time, whose yield is $93 \%$. The response surface indicates that, as molar ratio increases, yield decreases. This is different from the results observed by Feroldi et al. (2014), which suggested that in order to obtain a higher yield it is necessary to increase molar ratio in palm oil biodiesel production. Off the surface maximum, the yield decreases, especially for a molar ratio of $8: 1$ and 80 minutes, illustrated by the dark blue color on surface, resulting in a yield of 70\%. According to Guerrero-Peña et al. (2013), a possible cause of this effect is linked to the reversibility reaction, due to long reaction time, resulting in a decrease of methyl esters production.

Sukjit and Punsuvon (2013), while also using the RSM determined optimum conditions for palm oil biodiesel production at a molar ratio of 7:1, temperature of $60^{\circ} \mathrm{C}$ and 70 minutes reaction time with a proportion of $1.2 \% \mathrm{KOH}$ catalyst, resulting in a yield of $96.24 \%$. Wong et al. (2015), using RSM, observed that the highest yield of $97.67 \%$ was obtained by molar ratio of $13.04: 1$, reaction time of 2.67 hours, and a proportion of $3.60 \%$ of catalyst.

Using the RSM and the Taguchi method, Tan et al. (2017) found a biodiesel yield around 95\% under optimal reaction conditions at a temperature of $65^{\circ} \mathrm{C}, 1.9$ at 2 hours' time and a molar ratio of 10 at 11:1, indicating that the integration of both methods is practically effective. However, RSM is more reliable in predicting the nonlinear relationship between the processing variables and response.

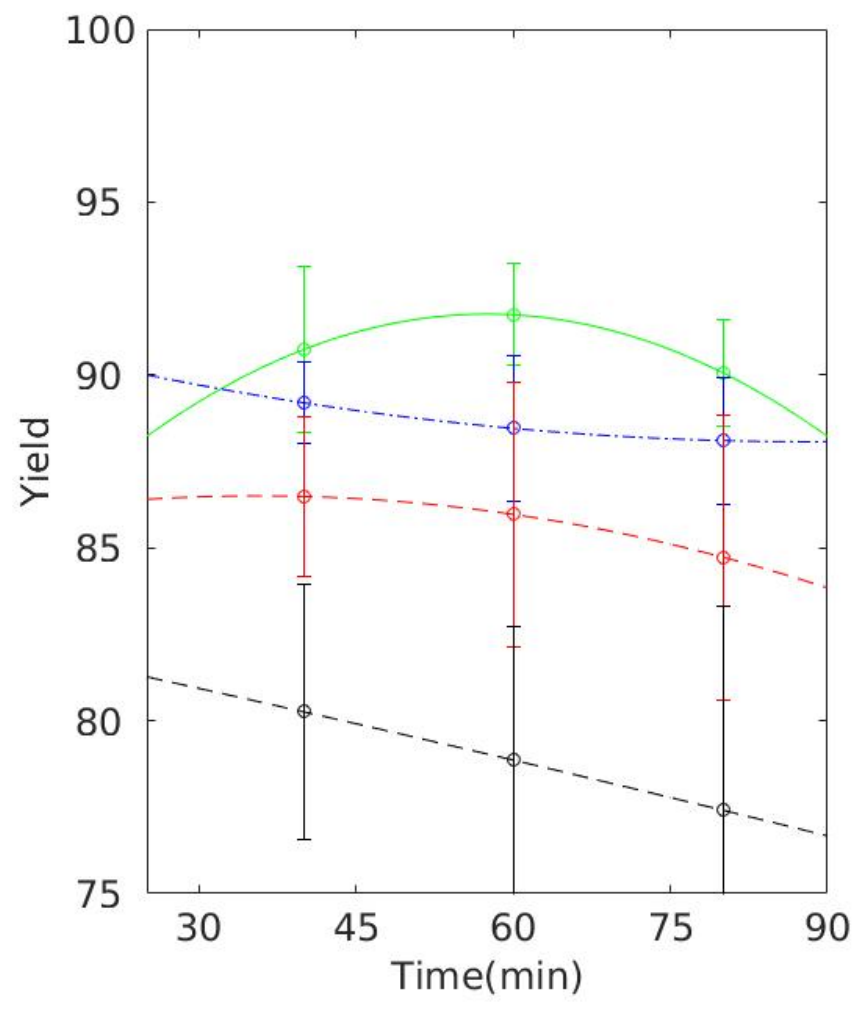

Figure 3 - Average and standard deviation of the experimental set (molar ratio) for $(\mathrm{A})$ temperature $\left({ }^{\circ} \mathrm{C}\right)$ and $(\mathrm{B})$ time (minutes). 
According to the results of Alkabbashi et al. (2009), the optimal conditions for biodiesel production with palm oil using methanol in the transesterification process were a reaction time of $60 \mathrm{~min}$ utes, a temperature of $60^{\circ} \mathrm{C}$, a molar ratio of $10: 1\left(\mathrm{~m} . \mathrm{m}^{-1}\right)$, and a proportion catalyst of $1.4 \%$ based on the oil mass, thus obtaining a yield of $93.6 \%$.

These results corroborate those obtained by Paula et al. (2017), which state that the characteristic molar ratio of the reaction is $3: 1$, meaning that for every 3 moles of alcohol, $1 \mathrm{~mol}$ of triglycerides is required for the stoichiometric balance of the complete transesterification reaction to ensure that all oil is consumed in the process and transformed into methyl ester and glycerin.

The results found in the current study also corroborate with Uribe et al. (2014), as the authors state that methanol has high toxicity, although its advantages refer to the greater use in biofuel plants for biodiesel production, once it is more reactive and relatively cheaper than ethanol, requiring a shorter reaction time and lower molar ratios.
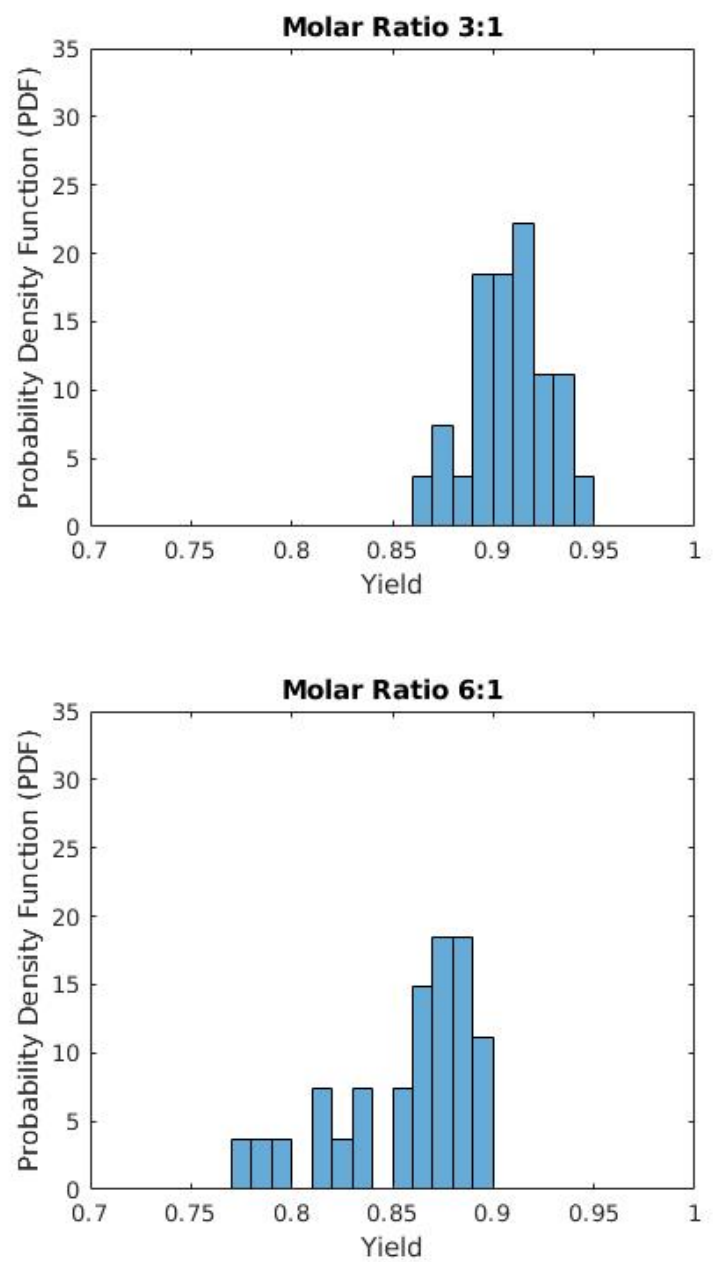

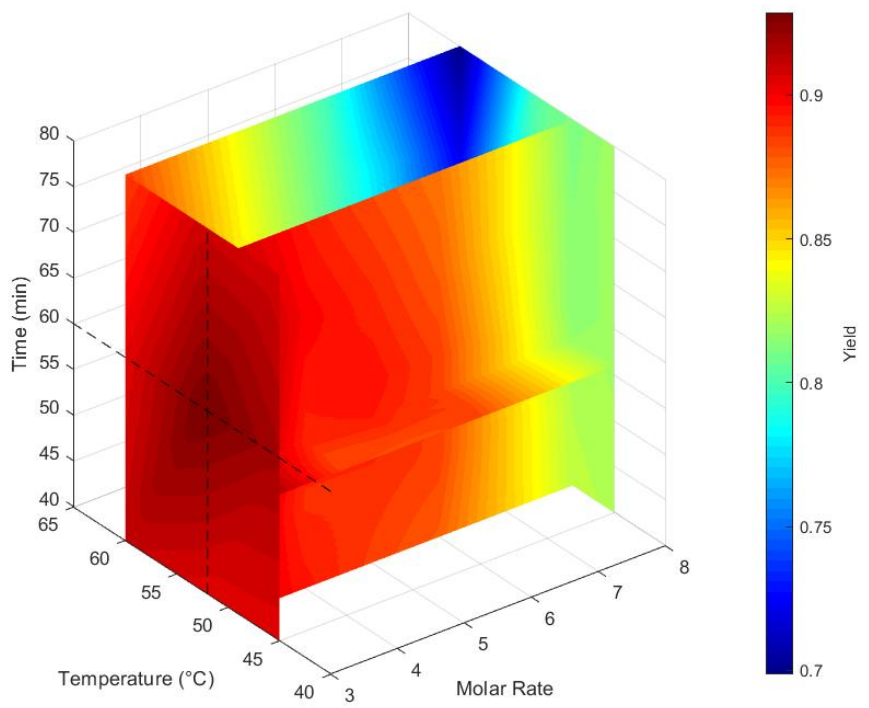

Figure 5 - Response surface of biodiesel production yield based on molar ratio, temperature, and time.
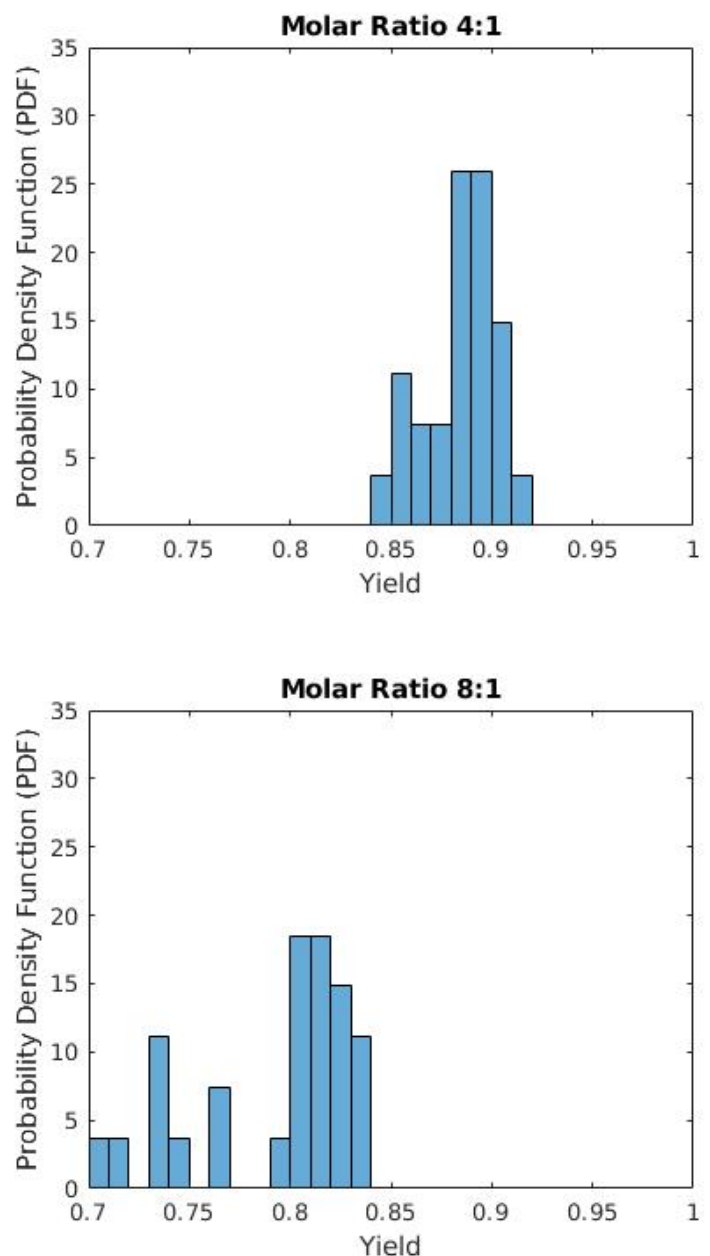

Figure 4 - Normalized probability distribution of production yields for 3:1, 4:1, 6:1 and 8:1 molar ratios. 
The optimization method results from the importance of improving the performance of the systems and processes without increasing the costs. The RSM is a set of statistical and mathematical techniques used for the development, improvement and optimization of processes, in which the response is influenced by several variables, with the goal of optimizing the response (Khuri and Mukhopadhyay, 2010).

\section{Conclusions}

Based on the methodology and the results, the molar ratio was the most influential variable in the production yield of palm oil biodiesel using alkali catalyst and methyl route. Through response methodology and variation of the production factors (molar ratio, temperature, and time), the highest yield was for the molar ratio of $3: 1,52^{\circ} \mathrm{C}$ and
60 minutes. This result varies from those previously investigated in other studies, which generally had increased yields for higher molar ratios and indicated that when the molar ratio increases, the yield increases as well, opposing the results in the current study.

The produced biodiesel was characterized according to specific mass and kinetic viscosity properties, and the found values are included in Brazilian, American, and European standards. Therefore, the palm oil biodiesel has may be used as fuel for igniting compression engines.

In relation to the biodiesel characterization, using the H1 NMR technique, the transesterification reaction yield for the $3: 1$ palm oil biodiesel reached $79.50 \%$. Using gas chromatography, the fatty acids present in the 3:1 palm oil biodiesel showed predominance of palmitic and oleic acids.

\section{Contribution of authors:}

Silva, F.C.: Conceptualization, Methodology, Validation, Formal analysis, Investigation, Data curation, Writing — original draft, Writing — review \& editing, Visualization, Supervision, Project administration. Guardiola, J.F.H.: Conceptualization, Methodology, Validation, Formal analysis, Investigation, Data curation, Writing - original draft, Writing — review \& editing, Visualization, Project administration. Teixeira, L.P.: Methodology, Validation, Formal analysis, Investigation, Data curation. Maria, A.C.L.: Formal analysis, Data curation, Writing — original draft, Writing — review \& editing. Souza, L.: Validation, Formal analysis, Data curation, Writing - original draft. Belém, A.L.: Methodology, Validation, Formal analysis, Investigation, Data curation, Visualization.

\section{References}

Abdullah; Sianipar, R.N.R.; Ariyani, D.; Nata, I.F., 2017. Conversion of palm oil sludge to biodiesel using alum and $\mathrm{KOH}$ as catalysts. Sustainable Environment Research, v. 27, (6), 291-295. http://dx.doi.org/10.1016/j.serj.2017.07.002

Ahiekpor, J.C.; Kuwornoo, D.K., 2010. Kinetics of palm kernel oil and ethanol transesterification. International Journal of Energy and Environment, v. 1, (6), 1097-1108.

Ali, E.N.; Tay, C.I., 2013. Characterization of biodiesel produced from palm oil via base catalyzed transesterification. Procedia Engineering, v. 53, 7-12. http:// dx.doi.org/10.1016/j.proeng.2013.02.002

Ali, O.M.; Mamat, R.; Faizal, C.K.M., 2012. Palm biodiesel production, properties and fuel additives. International Review of Mechanical Engineering, v. $6,1573-1580$.

Ali, O.M.; Yusaf, T.; Mamat, R.; Abdullah, N.R.; Abdullah, A.A., 2014. Influence of Chemical Blends on Palm Oil Methyl Esters' Cold Flow Properties and Fuel Characteristics. Energies, v. 7, (7), 4364-4380. https://doi. org/10.3390/en7074364

Alkabbashi, A.N.; Alam, Z.; Mirghani, M.E.S.; Al-Fusaiel, A.M.A., 2009. Biodiesel production from crude palm oil by transesterification process. Jurnal of Applied Sciences, v. 9, (17), 3166-3170. https://doi.org/10.3923/ jas.2009.3166.3170

Ambat, I.; Srivastava, V.; Sillanpää, M., 2018. Recent advancement in biodiesel production methodologies using various feedstock: A review. Renewable and Sustainable Energy Reviews, v. 90, 356-369. https://doi.org/10.1016/j. rser.2018.03.069

American Society for Testing and Materials (ASTM). 2012. ASTM D 445: Standard Test Method for Kinematic Viscosity of Transparent and Opaque Liquids (and Calculation of Dynamic Viscosity). American Society for Testing and Materials.
Anguebes-Franseschi, F.; Córdova-Quiroz, A.; Cerón-Bretón, J.; Aguilar-Ucan, C.; Castillo-Martínez, G.; Cerón-Bretón, R.; Ruíz-Marín, A.; MontalvoRomero, C., 2016. Optimization of biodiesel production from African crude palm oil (Elaeis guineensis Jacq) with high concentration of free fatty acids by a two-step transesterification process. Open Journal of Ecology, v. 6, (1), 13-21. http://dx.doi.org/10.4236/oje.2016.61002

Avellaneda, F.A.V., 2010. Producción y caracterización de biodiesel de palma y de aceite reciclado mediante un proceso batch y un proceso continuo con un reactor helicoidal. Universitat Rouvira I Virgili (Accessed October 9, 2017) at: http://www.tdx.cat/bitstream/handle/10803/8588/Tesi.pdf?sequence $=1$

Brasil. 1999. Agência Nacional de Vigilância Sanitária. Resolução RDC n 482, de 23 de setembro de 1999. Dispõe sobre regulamento técnico para Fixação de Identidade e Qualidade de Óleos e Gorduras Vegetais. Diário Oficial da União.

Brasil. 2011. Lei ${ }^{\circ}$ 12.490, de 16 de setembro de 2011 (Accessed September 19, 2019) at: http://www.planalto.gov.br/ccivil_03/_Ato2011-2014/2011/Lei/ L12490.htm\#art1

Brasil. 2014. Resolução ANP no 45, de 25 de agosto de 2014. Especificação do Biodiesel (Accessed August 30, 2019) at: http://legislacao.anp.gov. $\mathrm{br} /$ ?path=legislacao-anp/resol-anp/2014/agosto\&item=ranp-45-2014

D’Agosto, M.D.A.; Silva, M.A.V.; Oliveira, C.M.; Franca, L.S.; Marques, L.G.; Murta, A.L.S.; Freitas, M.A.V., 2015. Evaluating the potential of the use of biodiesel for power generation in Brazil. Renewable and Sustainable Energy Review, v. 43, 807-817. http://dx.doi.org/10.1016/j.rser.2014.11.055

Fagundes, C.A.M., 2011. Síntese e caracterização de biodiesel metílico e etílico a partir de blendas dos óleos de tungue e de soja. Dissertation, Mastering in Technological and Environmental Chemistry, Programa de Pós-Graduação em Química Tecnológica e Ambiental, Universidade Federal do Rio Grande, Porto Alegre. 
Feng, Y.; Qiu, T.; Yang, J.; Li, L.; Wang, X.; Wang, H., 2017. Transesterification of palm oil to biodiesel using Brønsted acidic ionic liquid as high-efficient and eco-friendly catalyst. Chinese Journal of Chemical Engineering, v. 25, (9), 1222-1229. https://doi.org/10.1016/j. cjche.2017.06.027

Feroldi, M.; Cremonez, P.A.; Estevam, A., 2014. Dendê: do cultivo da palma à produção de biodiesel. Revista Monografias Ambientais, v. 13, (5), 3800-3808. http://dx.doi.org/10.5902/2236130814674

Ferreira, D.F., 2014. Sisvar: a guide for its bootstrap procedures in multiple comparisons. Ciência e Agrotecnologia, v. 38, (2), 109-112. https://doi. org/10.1590/S1413-70542014000200001

Ge, J.C.; Kima, H.Y.; Yoon, S.K.; Choi, N.J., 2020. Optimization of palm oil biodiesel blends and engine operating parameters to improve performance and PM morphology in a common rail direct injection diesel engine. Fuel, v. 260, 116326. https://doi.org/10.1016/j.fuel.2019.116326

Gonçalves, M.; Silva, F.C.; Lopes Maria, A.C.; Souza, L.A.; Oliveira, P.O., 2019. Produção e caracterização de biodiesel produzido com óleos unitários e misturas binárias. Revista Brasileira de Ciências Ambientais (Online), (53), 33-50. https://doi.org/10.5327/Z2176-947820190426.

Guerrero-Peña, A.; Anguebes-Franseschi, F.; Castelán-Estrada, M.; Morales-Ramos, V.; Córdova-Quiroz, A.V.; Zavala-Loría, J.C.; BolañosReinoso, E., 2013. Optimización de la síntesis de biodiésel a partir de aceite crudo de palma africana (Elaeis guineensis Jacq). Agrociencia, v. 47, (7), 649-659 (Accessed April, 2, 2020) at: http://www.scielo.org.mx/ scielo.php?script=sci_arttext\&pid=S1405-31952013000700002\&lng=en\& nrm $=$ iso

Issariyakul, T.; Dalai, A.K., 2014. Biodiesel from vegetable oils. Renewable and Sustainable Energy Reviews, v. 31, 446-471. http://dx.doi.org/10.1016/j. rser.2013.11.001

Khuri, A.I.; Mukhopadhyay, S., 2010. Response surface methodology. WIREs Computational Statistics, v. 2, (2), 128-149. https://doi.org/10.1002/wics.73

Kim, H.Y.; Ge, J.C.; Choi, N.J., 2019. Effects of Fuel Injection Pressure on Combustion and Emission Characteristics under Low Speed Conditions in a Diesel Engine Fueled with Palm Oil Biodiesel. Energies, v. 12, (17), 3264. https://doi.org/10.3390/en12173264

Kong, S.; Loh, S.; Bachmann, R.T.; Rahim, S.A.; Salimon, J., 2014. Biochar from oil palm biomass: A review of its potential and challenges. Renewable and Sustainable Energy Reviews, v. 39, 729-739. http://dx.doi.org/10.1016/j. rser.2014.07.107

Kumar, A.; Shukla, S.K.; Tierkey, J.V., 2016. A Review of Research and Policy on Using Different Biodiesel Oils as Fuel for C.I. Engine. Energy Procedia, v. 90, 292-304. http://dx.doi.org/10.1016/j.egypro.2016.11.197

Kuss, V.V.; Kuss, A.V.; Rosa, R.G.; Aranda, D.A.G.; Cruz, Y.R., 2015. Potential of biodiesel production from palm oil at Brazilian Amazon. Renewable and Sustainable Energy Reviews, v. 50, 1013-1020. http://dx.doi.org/10.1016/j. rser.2015.05.055

Lebid, T.; Henkes, J.A., 2015. Óleo de dendê na produção de biodiesel: um estudo de caso das vantagens e desvantagens econômica, ecológica e social da cultura desta oleaginosa para a produção de biodiesel. Revista Gestão Sustentabilidade Ambiental, v. 4, (1), 416-447. http://dx.doi.org/10.19177/rgsa. v4e12015416-447

Lima, L.S.; Barbosa, T.P.; Silva, L.F.B.; Santo Filho, D.M.E.; Castro, C.S.C.; Santos Júnior, J.J.P.; Siqueira, J.R.R.; Barbosa, A.P.F.; Marteleto, P.R.; Rodrigues, C.R.C.; Pereira, R.G., 2010. Biodiesel Density Characterization using a Pycnometer. In: Metrology Symposium, Santiago de Querétaro, 2010. Simposio de Metrología, p. 1-9.
Lôbo, I.P.; Ferreira, S.L.C.; Cruz, R.S., 2009. Biodiesel: parâmetros de qualidade e métodos analíticos. Química Nova, v. 32, (6), 1596-1608. https://doi. org/10.1590/S0100-40422009000600044

Mancini, A.; Imperlini, E.; Nigro, E.; Montagnese, C.; Daniele, A.; Orrù, S.; Buono, P., 2015. Biological and Nutritional Properties of Palm Oil and Palmitic Acid: Effects on Health. Molecules, v. 20, (9), 17339-17361. https://doi. org/10.3390/molecules200917339

Marques, M.V.; Naciuk, F.F.; Mello, A.M.S.; Seibel, N.M.; Fontoura, L.A.M., 2010. Fatty ester content determination in soybean methyl biodiesel by gas chromatography using ethyl oleate as internal standard, v. 33, (4), 978-980. http://doi.org/10.1590/S0100-40422010000400039

Mekhilef, S.; Siga, S.; Saidurb, R., 2011. A review on palm oil biodiesel as a source of renewable fuel. Renewable and Sustainable Energy Reviews, v. 15, (4), 1937-1949. http://dx.doi.org/10.1016/j.rser.2010.12.012

Ong, H.C.; Mofijur, M.; Silitonga, A.; Gumilang, D.; Kusumo, F.; Mahlia, T., 2020. Physicochemical Properties of Biodiesel Synthesised from Grape Seed, Philippine Tung, Kesambi, and Palm Oils. Energies, v. 13, (6), 1319. https://doi. org/10.3390/en13061319

Paula, C.D.; Barros, F.J.S.; Correia, L.M.; Vieira, R.S., 2017. Avaliação de catalisador a base de conchas de ostras para a produção de biodiesel utilizando planejamento fatorial. Holos, v. 1, 316-324. https://doi.org/10.15628/ holos.2017.5204

Porcayo-Calderon, J.C.; Rivera-Muñoz, E.M.M.; Peza-Ledesma, C.; CasalesDias, M.; Escalera, L.M.M.; Canto, J.; Martinez-Gomez, L., 2017. Sustainable Development of Palm Oil: Synthesis and Electrochemical Performance of Corrosion Inhibitors. Journal of Electrochemical Science and Technology, v. 8, (2), 133-145. https://doi.org/10.5229/JECST.2017.8.2.133

Ramos, L.P.; Silva, F.R.; Mangrich, A.S.; Cordeiro, C.S., 2011. Biodiesel Production Technologies. Revista Virtual de Química, v. 3, (5), 385-405. http:// dx.doi.org/10.5935/1984-6835.20110043

Razack, S.A.; Duraiarasan, S., 2016. Response surface methodology assisted biodiesel production from waste cooking oil using encapsulated mixed enzyme. Waste Management, v. 47, part A, 98-104. https://doi.org/10.1016/j. wasman.2015.07.036

Rincón, L.E.; Jaramillo, J.J.; Cardona, C.A., 2014. Comparison of feedstocks and technologies for biodiesel production: An environmental and technoeconomic evaluation. Renewable Energy, v. 69, 479-487. https://doi. org/10.1016/j.renene.2014.03.058

Rodrigues, R.; Padilha, A.C.; Mattos, P., 2011. Princípios da produção mais limpa na cadeia produtiva do biodiesel: análise da indústria de óleo vegetal e usina de biodiesel. Revista Brasileira de Ciências Ambientais (Online), (20), 1-11.

Roschat, W.; Phewphonga, S.; Khunchaleec, J.; Moonsinc, P., 2018. Biodiesel production by ethanolysis of palm oil using $\mathrm{SrO}$ as a basic heterogeneous catalyst. Materials Today: Proceedings, v. 5, (6), part 1, 13916-13921. https:// doi.org/10.1016/j.matpr.2018.02.040

Ruschel, C.F.C.; Ferrão, M.F.; Santos, F.P.; Samios, D., 2016. Otimization of transesterification double step process (TDSP) to the production of biodiesel through doehlert experimental design. Química Nova, v. 39, (3), 267-272. https://doi.org/10.5935/0100-4042.20160018

Sarkar, J.; Bhattacharyya, S., 2012. Operating characteristics of transcritical $\mathrm{CO} 2$ heat pump for simultaneous water cooling and heating. Arch Thermodyn, v. 33, (4), 23-40. https://doi.org/10.2478/v10173-012-0026-8

Sawin, J.L.; Seyboth. K.; Wverisson, F., 2017. Renewables 2017 Global Status Report. Paris (Accessed October 6, 2017) at: https://www.ren21.net/wpcontent/uploads/2019/05/GSR2017_Full-Report_English.pdf 
Sukjit, T.; Punsuvon, V., 2013. Process Optimization of Crude Palm Oil Biodiesel. European International Journal of Science Technology, v. 2, (7), 49-56.

Tan, Y.H.; Abdullah, M.O.; Nolasco-Hipolito, C.; Zauzi, N.S.A., 2017. Application of RSM and Taguchi methods for optimizing the transesterification of waste cooking oil catalyzed by solid ostrich and chickeneggshell derived $\mathrm{CaO}$. Renewable Energy, v. 114, part B, 437-447. https://doi. org/10.1016/j.renene.2017.07.024

Tziourtzioumis, D.N.; Stamatelos, A.M., 2019. Diesel-Injection Equipment Parts Deterioration after Prolonged Use of Biodiesel. Energies, v. 12, (10), 1953. https://doi.org/10.3390/en12101953

Uribe, R.A.M.; Alberconi, C.H.; Tavares, B.A., 2014. Produção de biodiesel a partir do sebo bovino; viabilidade econômica e métodos de produção. In: Congresso Nacional de Excelência e Gestão, Bauru.

Vargas, F.A.A., 2010. Producción y caracterización de biodiesel de palma y de aceite reciclado mediante un proceso batch y un proceso continuo con un reactor helicoidal. Tesis de Doctorado, Universitat Rovira I Virgili, Spain.
Victorino, T.; Pereira, R.; Fiaux, S., 2016. Aproveitamento da glicerina de biodiesel obtida a partir de óleo de fritura para o cultivo do fungo Aspergillus niger. Revista Brasileira de Ciências Ambientais (Online), (42), 56-66. https:// doi.org/10.5327/Z2176-947820160107

Wong, Y.C.; Tan, Y.P.; Taufiq-Yap, Y.H.; Ramli, I., 2015. An Optimization Study for Transesterification of Palm Oil using Response Surface Methodology (RSM). Sains Malaysiana, v. 44, (2), 281-290. http://dx.doi.org/10.17576/jsm-2015-4402-17

Yoon, S.K.; Ge, J.C.; Choi, N.J., 2019. Influence of Fuel Injection Pressure on the Emissions Characteristics and Engine Performance in a CRDI Diesel Engine Fueled with Palm Biodiesel Blends. Energies, v. 12, (20), 3837. https:// doi.org/10.3390/en12203837

Yusop, A.F.; Mamat, R.; Yusaf, T.; Najafi, G.; Yasin, M.H.M.; Khathri, A.M., 2018. Analysis of Particulate Matter (PM) Emissions in Diesel Engines Using Palm Oil Biodiesel Blended with Diesel Fuel. Energies, v. 11, (5), 1039. https:// doi.org/10.3390/en11051039

Zahan, K.A.; Kano, M., 2018. Biodiesel Production from Palm Oil, Its ByProducts, and Mill Effluent: A Review. Energies, v. 11, (8), 2132. https://doi. org/10.3390/en 11082132 